\title{
Pestalotia Leaf Spot and Fruit Rot of Strawberry ${ }^{1}$
}

\author{
Juliana S. Baggio and Natalia A. Peres ${ }^{2}$
}

\section{Introduction}

Pestalotiopsis-like fungi cause diseases on many different species of plants worldwide, including strawberry. The pathogen is not new to strawberry and was first reported causing fruit rot in Florida and Israel in the 1970s. In the last decade, the fungus was associated with root and crown rots in Florida and other strawberry-producing areas. During the 2018-19 and 2019-20 strawberry seasons, severe and unprecedented outbreaks were reported in Florida, characterized by symptoms on nearly all plant parts, including roots, crowns, petioles, fruit, and leaves (Figure 1). Yield was severely affected, and in several cases, entire fields were rendered uneconomical to harvest and destroyed. The common link among these outbreaks was the nursery source of the transplants. Unfortunately, most of the commercial strawberry cultivars grown in Florida are susceptible, and currently there are no fungicides labeled to control this disease in the United States or elsewhere. This publication describes the disease and its causal agent and briefly covers what is known about disease development and control practices. This document will provide valuable information to strawberry nursery and fruit production growers.

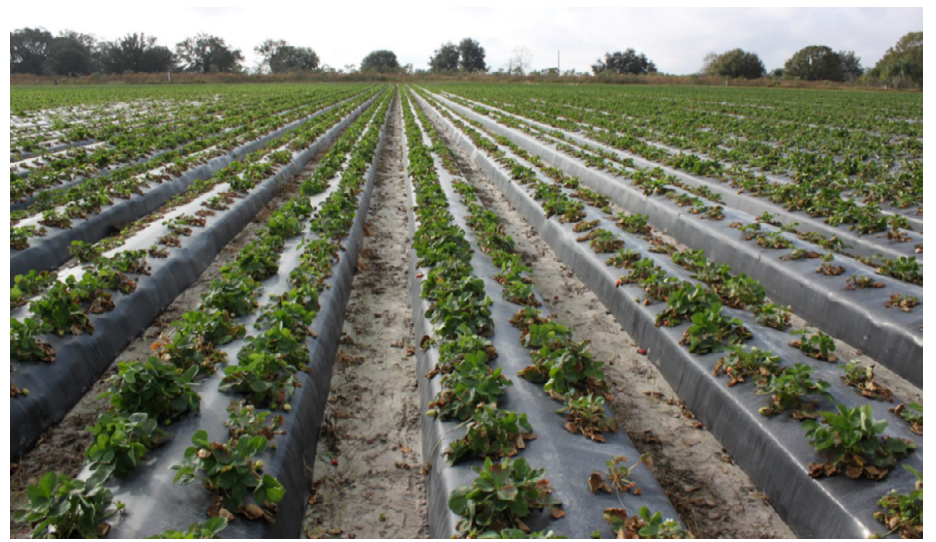

Figure 1. Pestalotia leaf spot and fruit rot outbreak in Florida strawberry fields.

Credits: UF/IFAS GCREC

\section{Causal Agent and Symptoms}

The taxonomy of this pathogen is confusing because it has gone through multiple reclassifications over the years. Researchers in Florida and Israel (Howard and Albregts 1973; Keneth et al. 1968) reported it for the first time on strawberry as Pestalotia longisetula. These reports characterized it mainly as a fruit rot pathogen. Based on spore type and other morphological characteristics, the pathogen was subsequently reclassified as Pestalotiopsis longisetula (Steyaert 1955). More recently, strawberry isolates were identified as Neopestalotiopsis spp. in reports describing a pathogen of strawberry roots and crowns (Chamorro

1. This document is PP357, one of a series of the Plant Pathology Department, UF/IFAS Extension. Original publication date September 2020. Visit the EDIS website at https://edis.ifas.ufl.edu for the currently supported version of this publication.

2. Juliana S. Baggio, postdoctoral associate, and Natalia A. Peres, professor, Plant Pathology Department, UF/IFAS Gulf Coast Research and Education Center, Wimauma, FL 33598.

The use of trade names in this publication is solely for the purpose of providing specific information. UF/IFAS does not guarantee or warranty the products named, and references to them in this publication do not signify our approval to the exclusion of other products of suitable composition. All chemicals should be used in accordance with directions on the manufacturer's label.

The Institute of Food and Agricultural Sciences (IFAS) is an Equal Opportunity Institution authorized to provide research, educational information and other services

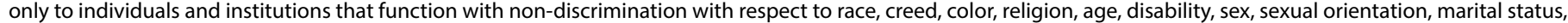

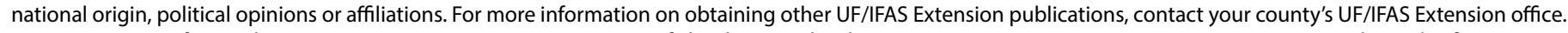
U.S. Department of Agriculture, UF/IFAS Extension Service, University of Florida, IFAS, Florida A \& M University Cooperative Extension Program, and Boards of County Commissioners Cooperating. Nick T. Place, dean for UF/IFAS Extension. 
et al. 2016; Obregón et al. 2018). According to the most recent studies, isolates reported in the past as Pestalotiopsis longisetula should be identified as Neopestalotiopsis rosae (Baggio et al. 2020). These isolates are most commonly found causing symptoms on roots and crowns during plant establishment. Belowground symptoms are characterized by darkening of the roots and orange-brown necrosis in the crowns, which contribute to stunting or poor establishment after transplanting. Aboveground symptoms range from stunting and wilting to eventual collapse of the entire plant (Figure 2). In some cases, the fungus is isolated along with other root and crown pathogens (Macrophomina phaseolina, as well as Colletotrichum and Phytophthora species). The fungus has always been considered a weak or secondary pathogen and was never a major concern in the strawberry industry until recently.

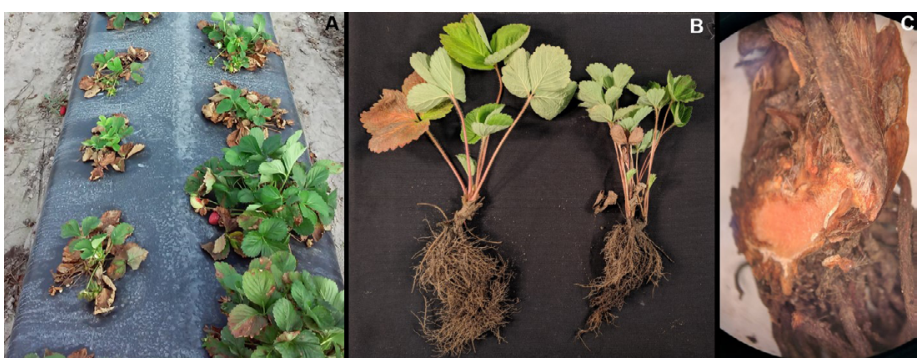

Figure 2. Symptoms caused by Neopestalotiopsis spp.: A) stunting of plants caused by root and/or crown infection; B) darkening and underdevelopment of roots; and $\mathbf{C}$ ) orange-brown necrosis in the crowns.

Credits: UF/IFAS GCREC

Studies performed at the UF/IFAS Gulf Coast Research and Education Center (GCREC) in Wimauma, FL, indicate that isolates from recent outbreaks are more aggressive and may belong to a new, heretofore-unnamed Neopestalotiopsis species. In the recent outbreaks, leaves and fruit were infected early, and some were severely damaged. As the disease progresses, the pathogen can also be isolated from diseased petioles, crowns, and roots. Fruit symptoms can be confused with anthracnose fruit rot (Figure 3). More information about anthracnose fruit rot can be found at https:// edis.ifas.ufl.edu/pp130. Leaf spots initially can be confused with other fungal diseases such as leaf blotch (Gnomonia comari), Phomopsis leaf blight (Phomopsis obscurans), common leaf spot (Mycosphaerella fragariae), Cercospora leaf spot (Cercorspora fragariae), and leaf scorch (Diplocarpon earliane). Thus, accurate diagnosis is extremely important, because disease management practices may differ.

Young fruit spots are 2-4 $\mathrm{mm}$ in diameter, dry, light tan, slightly sunken, and irregular in shape. Lesions grow in size and eventually are covered by dark fruiting bodies (acervuli), which exude spores into shiny black liquid matrix droplets (Figures 3 and 4).

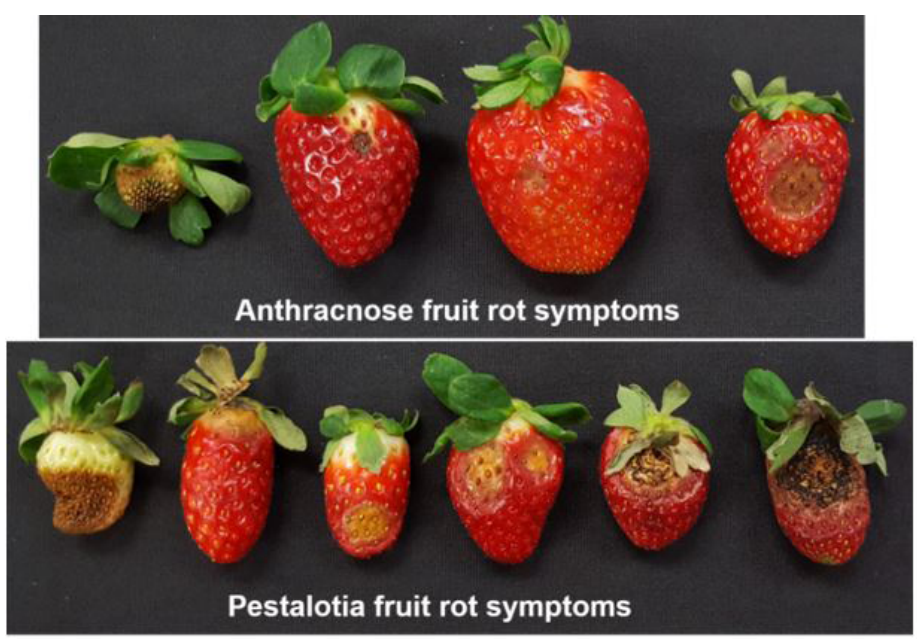

Figure 3. Anthracnose fruit rot symptoms caused by Colletotrichum acutatum and Pestalotia fruit rot symptoms caused by Neopestalotiopsis sp.

Credits: UF/IFAS GCREC

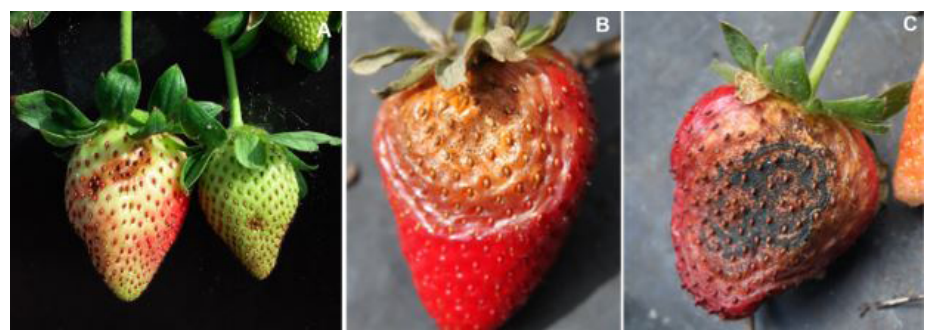

Figure 4. Pestalotia fruit rot lesions on $\mathbf{A}$ ) green fruit (early stage development), B) ripe fruit and calix, and C) late-stage lesions covered by black spore mass of Neopestalotiopsis sp.

Credits: UF/IFAS GCREC

Light- to dark-brown spots of different sizes are irregularly distributed on infected leaves. In more advanced stages, the spots increase in size, and although many are roughly circular, some become irregular upon reaching the leaf margins. Dark fruiting bodies (acervuli) containing the fungal spores develop in the tan centers of older necrotic tissues (Figure 5).

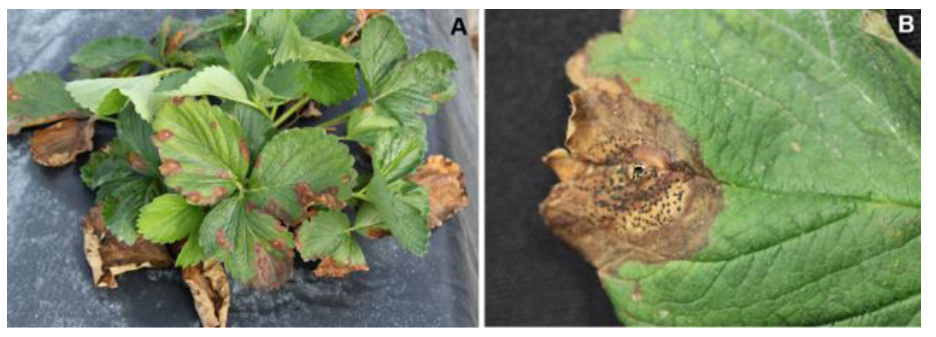

Figure 5. Pestalotia leaf spot symptoms: A) leaves with light- to dark-brown spots and B) older necrotic leaf tissue covered by black structures (spores) of Neopestalotiopsis sp.

Credits: UF/IFAS GCREC

Spores are exuded in black droplets as described for fruit lesions, and also in dark sooty columns when relative humidity is high (Figure 6). Mass spotting often produces blight-like necrosis of broad areas of the leaf, eventually killing it. The disease can also contribute to poor development of the plants, which become stunted with smaller, 
weaker leaves. The pathogen eventually infects roots and crowns, producing belowground symptoms as previously described.

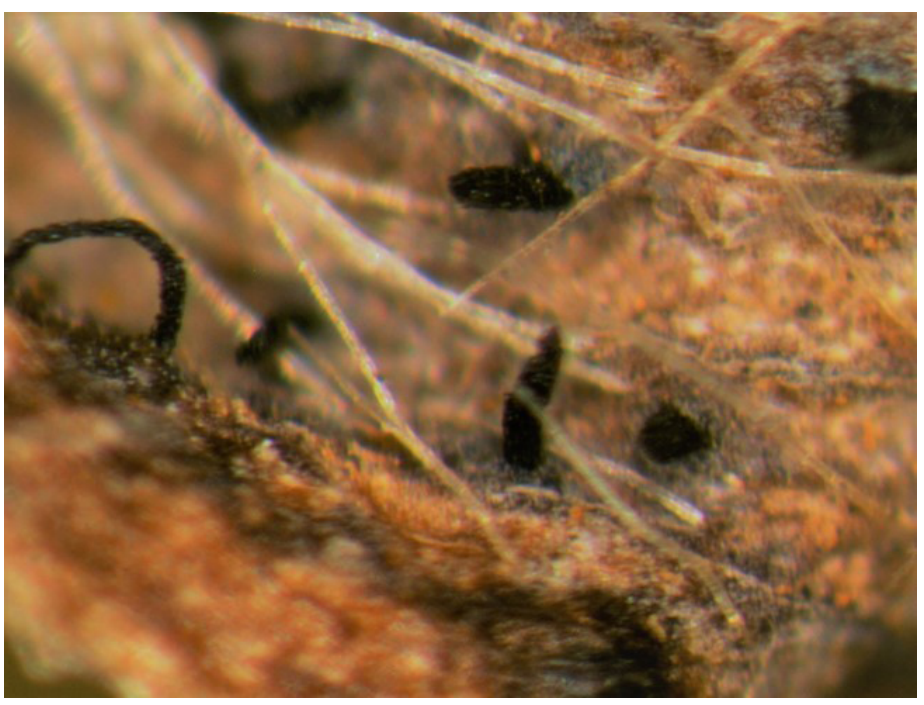

Figure 6. Exuded spores in black droplets and in dark sooty columns when relative humidity is high, but rains and dews are absent. Picture taken through dissecting microscope at 40x.

Credits: James Mertely, UF/IFAS GCREC

\section{Disease Development and Spread}

Our studies suggest that the primary source of inoculum for epidemics in Florida is infected strawberry transplants from specific nurseries. However, the pathogen can spread to other fields locally. The disease is generally favored by consecutive and prolonged rain events, and by temperatures above $50^{\circ} \mathrm{F}\left(10^{\circ} \mathrm{C}\right)$, with an optimum between $77^{\circ} \mathrm{F}$ and $86^{\circ} \mathrm{F}\left(25^{\circ} \mathrm{C}\right.$ and $\left.30^{\circ} \mathrm{C}\right)$. The fungus produces spores on the surface of infected tissues that can be spread by water, farm equipment, and field workers during harvest and cleaning operations. Under favorable conditions, the pathogen spreads very rapidly. However, more studies are needed to clarify the origin, spread, and survival of this new and damaging species of Neopestalotiopis affecting strawberry.

\section{Control}

Management of Neopestalotiopsis involves a combination of cultural practices and chemical strategies. Further studies are needed to develop integrated strategies for disease management in strawberry nursery and production fields.

\section{Cultural}

Acquiring disease-free transplants, when possible, is the best practice to avoid the introduction of the pathogen in a field and escape or delay the occurrence of the disease. However, symptoms are not always easily recognized on transplants after their arrival in Florida, and thus routine inspections at the nursery level should be implemented.
Limiting field operations such as harvesting and spraying when plants are wet is important to minimize dispersal within and between fields. Spread can be minimized by hand sanitation, cleaning and disinfestation of equipment, and performing farm operations in affected fields at the end of the day.

All currently commercially grown cultivars are susceptible to the disease. However, 'Florida Beauty' is the most susceptible. 'Florida Brilliance, 'Florida Radiance', and Sweet Sensation ${ }^{\oplus}$ 'Florida127' showed intermediate susceptibility.

\section{Chemical}

Although there are no fungicides currently labeled for the control of Neopestalotiopsis on strawberry, screening studies and/or field trials at UF/IFAS GCREC showed that Switch $^{\oplus}$ 62.5 WG (fludioxonil + cyprodinil) and Thiram SC (thiram) were the most effective in controlling the pathogen. Bravo Weather Stik ${ }^{\circledast}$ (chlorothalonil), Manzate ${ }^{\varpi}$ Pro-Stick $^{\mathrm{TM}}$ (mancozeb), Omega ${ }^{\circledR}$ (fluazinam), and Miravis ${ }^{\circledast}$ Prime (fludioxonil + pydiflumetofen) also offered some degree of disease control. Bravo, Manzate ${ }^{\oplus}$, and Omega ${ }^{\oplus}$ are not registered for strawberry production fields but could be good options for strawberry nurseries. Bravo is already registered for nursery use and Omega ${ }^{\oplus}$ is in the final steps of registration. Our industry greatly relies on fludioxonil (one of the active ingredients in Switch ${ }^{\odot}$ and Miravis ${ }^{\odot}$ Prime) for the control of other diseases, such as Botrytis and Anthracnose fruit rots. The overuse of these products can lead to increased selection for fungicide resistance. Therefore, applications need to be limited to the maximum number allowed on the label. In fact, isolates of the new Neopestalotiopsis have already been found to have resistance to the strobilurin fungicides (Abound, Cabrio, Flint, etc.). Thus, effective alternative products are greatly needed.

\section{Additional Information}

More information on products for sanitation of equipment and tools is available at https://edis.ifas.ufl.edu/fs077 and https://edis.ifas.ufl.edu/fs366.

For approved decontamination products and methods, this material developed for citrus canker may be helpful: http://www.freshfromflorida.com/content/download/9901/135674/decontamination.pdf. 


\section{Literature Cited}

Baggio, J. S., B. B. Forcelini, N.-Y. Wang, R. G. Ruschel, J. C. Mertely, and N. A. Peres. 2020. "Outbreak of Leaf Spot and

Fruit Rot in Florida Strawberry Caused by Neopestalotiopsis spp." Plant Disease, First Look. https://doi.org/10.1094/

PDIS-06-20-1290-RE

Chamorro, M. C., A. Aguado, and B. De los Santos. 2016. "First Report of Root and Crown Rot Caused by Pestalotiopsis clavispora (Neopestalotiopsis clavispora) on Strawberry in Spain." Plant Dis. 100:1495.

Howard, C. M., and E. E. Albregts. 1973. "A Strawberry Fruit Rot Caused by Pestalotia longisetula." Phytopathology 63:862-863.

Kenneth, R. G., R. Barkai-Golan, and D. Netzer. 1968. “A Pestalotia Fruit Rot of Strawberry in Israel." Plant Dis. Rep. 52:472-474.

Obregón, V. G., N. G. Meneguzzi, J. M. Ibañez, E. Lattar, and D. S. Kirschbaum. 2018. "First Report of Neopestalotiopsis clavispora Causing Root and Crown Rot on Strawberry Plants in Argentina." Plant Dis. 102:1856.

Steyaert, R. L. 1955. “Pestalotia, Pestalotiopsis et Truncatella." Bulletin Jardin Botanique État Bruxelles 25:191-199. 